De kristne i Midtøsten' er i dag under press fra mange ulike hold. En konsekvens av dette er emigrasjon. Er den kristne tilstedeværelsen i Midtøsten i ferd med å forsvinne? Vil de som blir igjen gå inn i sin historiske rolle som "dhimmis"; et tolerert, men underlegent minoritetssamfunn?

\title{
Vil de fortsatt kunne være der?
}

NOEN TANKER OM DE KRISTNES SITUASJON I MIDTØSTEN I DET NYE ÅTUSEN

Egil Fossum er magister i statsvitenskap, opprinnelig fredsforsker. Tidligere førsteamanuensis i journalistikk, formann i Palestinakomiteen og redaktør av Klassekampen. Siste bok: «Hos de kristne i Midtøsten». Oslo: Emilia, 2003. 
TEKST: Egil Fossum

“JEG TENKER PÅ KANADA HVER DAG”, sier hun, koptisk-ortodoks kvinne i midten av 40-årene. Aldri før har hun ytret ønske om å forlate hjemlandet. Hennes identitet er knyttet til al-Minya, byen i øvre Egypt med sterk koptisk-ortodoks tilstedeværelse, hvor hun vokste opp og hvor hun har sin familie. Hva er nytt? Noe må ha langsomt bygget seg opp. Ja, slik er det. En datter, helt ung tenåring, er blitt demonstrativt tvangskysset av en gruppe muslimske gutter i full offentlighet, en ufattelig provokasjon i familiens øyne. Døtrene kan ikke lenger gå i fred på søndagsskolen; prestene må sende dem hjem fordi unge islamister trakasserer dem utenfor kirken, og her må man være klar over den enorme rollen søndagsskolene spiller for det koptiske religiøse livet og for fremveksten av den moderne koptiske identiteten. Plut- selig en dag kjenner hun selv en angst for å gå alene på gaten, etter et halvt liv i Kairo. På jobben ${ }^{2}$ blir hun anklaget av muslimske kolleger for å være tilhenger av den kristne Bush, tilhenger av det kristne korstoget, enda alle meget godt vet at både hun og mannen står den palestinske saken nær, har vist det i praksis og ellers har en helt klar holdning til usAs angrep på Irak.

Siden dette kommer fra hennes munn, er virkningen sterk; kanskje situasjonen for de kristne i Egypt er vanskeligere enn det er vanlig å tenke seg. Ja kanskje det er slik over hele regionen, og at man lett kan overse det fordi man føler en trang til å forsvare den arabiske verden mot en uvitende, generaliserende og aggressiv proisraelsk norsk kritikk. Ikke alle vil gå god for formuleringer som "forfølgelsen av de kristne i Midtøsten", men tar man virkelig innover seg hvor vanskelig situasjonen tross alt kan være for mange kristne av de forskjelligste trosretninger i landene rundt det indre Middelhav? Det er et faktum at veldig mange av Midtøstens kristne selv stiller spørsmålet: Kan vi fortsette å være her?3 Det er et vanskelig spørsmål å besvare. Det som er klart, og som alle kristne man møter snakker om, leg og lærd, er emigrasjonen, den massive og kontinuerlige emigrasjonen, som i denne omgang har vart i rundt 50 år. Ser vi en hel verden på vei til eksilet?

\section{Hvem er de kristne?}

Slik mange i Norge snakker om muslimene som én aktør, er det også lett å forenkle og snakke om de kristne i Midtøsten som en ensartet kategori, men går det an å snakke så selvfølgelig om dem på denne enkle måten? Det kommer an på ståsted, ser det ut til. De kristne selv ser seg 
som veldig ulike konfesjonelt, historisk og ofte etnisk-nasjonalt, selv om de innser at de på mange måter har noe viktig felles ettersom de deler sin utsatte og sårbare posisjon i dagens Midtøsten. En viss samordning mellom dem er riktignok blitt

\section{Områdets muslimer skiller i liten grad mellom trosretningene $i$ den ufullkomne, kristne religionen.}

utviklet gjennom to generasjoners økumenisk arbeid internasjonalt og regionalt, men det står ikke til å nekte at i samtale er det det distinkte ved egen trosretning som fremheves. Boken «Christianity. A History in the Middle East» ${ }^{4}$, nylig utgitt på engelsk av Middle East Council of Churches i Beirut, og med et økumenisk sikte, gir på sine 933 sider et overveldende inntrykk av kompleksitet, av dyptgående forskjeller side om side med de fineste distinksjoner innenfor det kristne kosmos.

Mange av områdets muslimer, på sin side, skiller i veldig liten grad mellom trosretningene innenfor den ufullkomne kristne åpenbaringsreligionen. Ett talende uttrykk for dette er angrepene på de palestinske kirkene på Vestbredden og i Gaza etter pave Benedikt xvis tale i september i fjor. Syv kirker ble angrepet, en av dem - den gresk-ortodokse kirken i Gaza by - hele fire ganger. Av de syv kirkene tilhørte bare en Paven i Roma, nemlig den latinske kirken i Rafidya i Nablus. Fire var ortodokse, i Nablus, i Tulkarm, i den store landsbyen Tobas på Vestbredden, i tillegg til den ortodokse kirken i Gaza. To var protestantiske, etter navnene å dømme, begge disse også i Rafidya i Nablus. Ingen konfesjonelle distinksjoner ble lagt til grunn. Av de to store kirkesamfunnene på Vestbredden, slapp den latinske, pave Benedikts egen kirke, lettest fra det, enda det er I6-I7 latinske kirker på Vestbredden. Men for skadegjørerne var nok en kirke en kirke, og at de latinske og de greskortodokse er historiske rivaler, gikk nok heller ikke inn i deres kalkulasjoner. "Tilgangen” på kirker er selvfølgelig varierende og må ha hatt en viss betydning da det ikke er mange katolske kirker i Gaza. Graden av lokale militante varierer også. Nablus var aldri et fredelig sted og hadde aldri mange kristne, men samlet sett, for det lille kristne kosmos, var dette et generelt angrep på de kristne, et tankevekkende og truende faktum.

Nå vil nok mange stille spørsmålet, hvem er egentlig de kristne? Ikke lett å beskrive: kirkebildet kan virke temmelig uoversiktlig for en europeer. Vi har de historiske kirkene, delt teologisk i tre etter synet på Kristi natur. Kristus var Guds sønn, en del av treenigheten, men han hadde også vært menneske. Hvordan skulle dette forstås og formuleres? Alt ettersom hvordan man vektla hans menneskelighet, hans guddommelighet og hvordan man beskrev forbindelsen mellom de to, skilte kirkene seg fra hverandre utover på 400-tallet. Først ble den retningen som senere ble den assyriske Østens kirke, hos oss i vest gjerne kalt "nestoriansk", skilt ut på kirkemøtet i Efesus i 43I, fordi den vektla hans menneskelighet, for å si det litt enkelt. Fortsatt er den ikke tatt inn i varmen som medlem av Middle East Council of Churches. Egypts koptere fikk dem ut og vil ikke ta dem tilbake enda det er gått I500 år. 20 år etter, på kirkemøtet i 
Khalkedon i 45I, og fortsatt på spørsmålet om Kristi natur, oppstod en dyp splittelse som lever til denne dag.

På den ene siden sto keiserens kirke i Konstantinopel, khalkedonerne, de som fikk flertall i Khalkedon, i dag kalt den gresk-ortodokse. På den andre siden sto de ikke-khalkedonske kirkene, i dag kalt de orientalsk-ortodokse kirkene. Her finner vi den koptisk-ortodokse kirken i Egypt, den syrisk-ortodokse kirken, først og fremst i Syria, Irak og Libanon og den armenskapostoliske kirken, i det arabiske Midtøsten, først og fremst i Libanon og Syria. Keiserens kirke, de gresk-ortodokse, sluttet opp om formuleringen "fullt ut Gud, fullt ut menneske”, for å forenkle nok en gang, mens de orientalske kirkene understreket Kristi guddommelighet. Alle disse fire kirkene som kjempet om definisjonene i Khalkedon, er kirker som hegner om tradisjonene og som regner seg som "østlige" og blant annet av den grunn føler seg beslektet i den moderne verden, men det er fortsatt ikke fullt kirkefellesskap over den khalkedonske skilleveggen. Det bør legges til at både katolikker og protestanter er khalkedonere. Dette som skjedde på 400-tallet var for øvrig slett ikke bare teologi, men handlet om distinkte kulturers forhold til keisermakten i Konstantinopel, egyptisk, syrisk, armensk.

Fra hver av disse historiske kirkene, avspaltet det seg fra midten av I500-tallet og frem til slutten av i80o-tallet en katolsk retning. Denne avspaltingen var resultatet av et komplisert samvirke mellom pavelige kirkeinteresser i Midtøsten, franske handelsinteresser og konflikter mellom mer moderne og mer tradisjonelle elementer innen disse kirkene selv, for å gi kortversjonen. Ut av den assyriske Østens kirke (nestorianerne) fikk vi de katolske kaldeerne, den største kirken i Irak. Fra de gresk-ortodokse fikk vi de gresk-katolske; fra de koptisk-ortodokse fikk vi de koptiskkatolske og videre på samme måte, henholdsvis de armensk-katolske og de syrisk katolske, alle med sine patriarkater som i moderkirkene. Disse unierte kirkene, som de kalles, ligger under Paven, men har beholdt mange av de østlige tradisjonene. I tillegg, i den katolske familien, har vi de latinske, innplantet direkte fra Roma av kirkepolitiske grunner, samt en av de originale syriske kirkene, maronittene i Libanon, et av regionens sterkeste kirkesamfunn. Dette gir i alt I2 trosretninger. Den I3. retningen, protestantene, fordeler seg på en lang rekke kirkesamfunn, hvorav bare fem kan sies å ha noe sterkt lokalt feste, Palestinas og Jordans anglikanere og lutheranere, samt avspaltede grupper koptere og armenere. Heftig misjonering og god økonomi har også gitt baptistene et lokalt fotfeste, forøvrig den eneste kirken som i dag helt åpent "beiter på" de andre kirkene. For å forenkle kirkebildet, ortodokse kirker fra regionen med katolske og protestantiske avskallinger og i tillegg maronitter og latinske (pavekirken). Vi står altså overfor en uhyre komplisert konfesjonell situasjon hvor de fleste kirkene finnes i de fleste landene, og hvor hvert land har sin toneangivende trosretning: de ortodokse kopterne i Egypt, de katolske maronittene i Libanon, de gresk-ortodokse i Syria, i Jordan og i de palestinske områdene (disse er ikke grekere, men arabere bortsett fra hierarkiet i Jerusalem), og endelig de gresk-katolske melkittene i Israel.

Vilkårene for de kristne i de ulike landene er ikke de samme, her rent stikko- 
rdsmessig: militær okkupasjon og isolasjon med et økonomisk kvelertak i Palestina; et minoritetsvennlig minoritetsregime i Syria, truet av USA med regimeskifte, et skremmende perspektiv for de kristne; splittet kristen leir i Libanon som går fra nederlag til nederlag; en relativt stabil situasjon i Jordan så lenge kongemakten overlever, men press fra islamistene; og i Egypt, et trykk på mange nivåer, diskriminering når det gjelder høyere stillinger, provokasjoner fra islamistene og et massivt sosialt trykk fra store deler av de muslimske massene. I Israel er forholdene annerledes, ikke minst er økonomien bedre. Dette har antagelig ført til en stabilisering av tallet på de kristne, særlig i Galilea. Det finnes også forskjeller i rettstilstanden til de kristne minoritetene, men det ligger utenfor denne artikkelen å ta opp; det er ikke engang sikkert at det er så viktig i det store bildet.

Men er det ikke noe felles? Jo da, de kristne i de ulike landene deler den dårlige økonomien med hverandre - og med muslimene. Mange av dem man snakker med kjenner uro for hva Israel kan finne på. Det er vel også temmelig klart at det å være små minoriteter, tildels veldig små, helt ned i 50.000 tilhengere, $i$ en urolig verdensdel hvor den politiske temperaturen er høy og den religiøse ladningen er sterk, må virke truende. De kristne har også en annen ting felles; de har ingen virkelige venner, ingen sanne venner med makt. Det er ingen kristen makt i Europa eller Amerika som prioriterer de kristne og deres interesser over andre interesser. Omsorgen for Mubarakregimet i Egypt er langt større enn omsorgen for kopterne; de kristne i Libanon, Palestina og selvfølgelig i Israel må vike plass for Israels statsinteresser og andre politiske interesser; de kristne i Jordan har liten politisk betydning mens de kristne i Syria beskyttes av et regime usa hater. Men om de ikke har venner og allierte i den kristne verden, så har de fortsatt en havn der - det er ikke så vanskelig for dem å slå seg ned der - og mange gjør det. Stilt overfor disse utfordringene, kan det være interessant å prøve å få et grep på ulikheter i sårbarhet blant de kristne.

\section{Sårbarhet}

Det finnes jo nasjonale skiller, men det er vanskelig å si hvor mye det betyr i vår sammenheng, i et emigrasjonsperspektiv. Den armenske kirken er ikke arabisk og er ikke på vei til å bli arabisert. På den annen side er den armenske diasporaen i Midtøsten meget gammel og har overlevd kriser og katastrofer i I500 år. Det finnes andre ikkearabiske kirker som er i ferd med å bli arabisert, for eksempel de mindre syriske kirkene, særlig fordi det prekes på arabisk selv om mye av liturgien er syrisk. Den koptiske kirken i Egypt har innslag av liturgi på koptisk, men er i praksis arabisk fordi det prekes på arabisk. Påstanden om kirkens hovedsakelig arabiske karakter vil vel ellers bestrides av mange. Den finnes gresk-ortodokse kristne i alle land. Dette er den største trosretningen etter den koptiskortodokse, fordelt på tre patriarkater, og menighetene er arabiske. Det er vanskelig å si hvor mye slike forskjeller betyr når det gjelder sårbarhet og ønsket om å emigrere. Noen er historisk sett emigrasjonsfolk eller folk som har vært på flukt. Andre er det ikke. Slik sett er det forskjell på for eksempel armenere, libanesere og egyptere.

Størrelse, antallet troende, er åpenbart et viktig forhold når det gjelder sårbarhet det ligger varierende grader av sårbarhet $\mathrm{i}$ 
varierende tallstørrelser og kanskje også i kompakthet, hvor tett lever de? Sammenhengen mellom kvantitet og kvalitet påvirker både følelsen av tilhørighet og trygghet hos de troende, og omfanget av de tjenester kirken som organisasjon kan tilby menighetene, prestetetthet, skoler - en hovedsak for alle trosretninger - aldershjem og et aktivt menighetsliv. Det finnes kirker som sitter med skoler fra gammelt av, for eksempel lutheranere i Homs i Syria, men som selv er blitt så få at flertallet av elevene er muslimer. Hva tjener de kristne på det? Velvilje, men noen form for misjonering kommer jo ikke på tale.

Tall er vanskelige; det finnes ikke løpende sammenliknbare tallserier for våre land. Det kan se ut som om de fleste nyere bøker tar utgangspunkt i anslag som den amerikanske misjonsprofessoren Norman A. Horner ${ }^{5}$ gjorde på slutten av ig8o-tallet. Viktige eksempler på dette er Andrea Pacinis «Christian Communities in the Arab Middle East» ${ }^{6}$ og Courbages og Fargues «Christians and Jews under Islam».

Den største kirken i Midtøsten er den koptisk-ortodokse kirken i Egypt. Antall ortodokse koptere er omstridt, men mest sannsynlig ligger tallet rundt fire millioner. Dette er en liten relativ størrelse, kanskje fem prosent av folketallet i Egypt, men et stort absolutt tall i "funksjonell forstand". Det koptiske samfunnet er stort nok til at det rommer alle samfunnsfunksjoner, inkludert skoler og sosialhjelp. Det finnes andre store kirker, for eksempel maronittene i Libanon, hvis andel av befolkningen er synkende, kanskje så vidt over I5 prosent. Disse er i absolutt forstand i samme situasjon som kopterne med evne og kraft til å arbeide over hele det religiøse, sosiale og politiske felt. Tilsvarende gjelder andre større kirker, for eksempel de greskortodokse i Syria og Libanon og de greske katolske og de ortodokse armenerne sammesteds.

Mange av de øvrige syriske kirkene er små. Bare en av dem, den syrisk-ortodokse, har mer enn 50.000 medlemmer i ett land, nemlig i Syria. Så hvor mye kan kirker med mellom 50.000 medlemmer til I50.000

\section{De kristne har også en annen ting felles; de har ingen virkelige venner, ingen sanne venner med makt.}

spredt over de fleste av landene i regionen, gjøre for menighetene sine? Katolikkene er i en litt spesiell stilling siden de tilhører en verdensomspennende kirkeorganisasjon. Protestantene får hjelp fra rike slektninger rundt Nord-Atlanteren. De ulike ortodokse kirkene sliter mer. De har ikke noe rikt og mektig sentrum utenfor regionen, men må stole på egne krefter.

Ikke bare antallet troende, men også trossamfunnets etnisk-nasjonale karakter har betydning. Noen kirkesamfunn har utviklet en sterk bevissthet om sine særpreg gjennom inngifte, annen avgrensning mot andre og dyrking av egne historiske tradisjoner over lang tid. Alle som møter Midtøstens kristne, ser hvilke ulikheter det er, for eksempel mellom de greskortodokse i Syria og Libanon og medlemmer av de ulike syriske kirkene. De greskortodokse lever spredt, hovedsakelig i byene og har i hundrevis av år utgjort et ledende skikt sammen med sunni-muslimene, uten noe egentlig kjerneområde eller "hjemland". I egen bevissthet er de 
arabere, mens mange av de syriske kirkene ikke ser seg slik og understreker sin annerledeshet, de er ikke-arabere i en arabisk kontekst. Kirkene har altså ulike egenskaper som kirkesamfunn, og man kan ikke uten videre generalisere, men noe har de definitivt felles: antallet medlemmer reduseres kontinuerlig gjennom emigrasjon. Hvor stor variasjonen i emigrasjonstilbøyelighet er mellom kirkesamfunnene, vites ikke. Nå er ikke emigrasjon noe nytt fenomen, men har gått i bølger de siste I50 årene. Høydepunktene er den store syrisk-libanesiske emigrasjonen før første verdenskrig og den nye bølgen fra I960-tallet og frem til i dag. Også et land som Egypt, som ikke i vesentlig grad har vært et emigrasjonsland, er blitt en del av dette veldige kristne exodus. På 6o-tallet kom de første koptisk-ortodokse kirkene utenfor regionen, i Tyskland og i England. I UsA og Kanada er det nå over I50 kirker, i Australia og på New Zealand nærmere 40, i Storbritannia snart 20 og i Europa ellers over 50. Det finnes også koptiske kirker i Afrika, Latin-Amerika og noen få andre steder i Midtøsten. Den koptisk-ortodokse diasporaen nærmer seg en halv million.

\section{Nok en gang "dhimmis"?}

Hvordan vil et drastisk synkende kristent folketall i de ulike landene påvirke sameksistensen mellom en stor muslimsk majoritet og små kristne minoriteter? Vil de kristne bli "dhimmis" igjen, minoriteter i en underordnet posisjon, men tolerert? Kanskje. Vil de bli beskyttet av statene også, slik de i islam har krav på som ahl al-dhimma, "paktens folk"? Vanskelig å si. Dr. Elie Karame, gresk-katolsk libaneser, leder av falangistpartiet på midten av 80-tallet, sa en gang: "Libanon er nå det eneste landet $\mathrm{i}$
Midtøsten med en konstitusjon som gir rettigheter og friheter til de kristne, og for muslimene også. Vi vil ikke være 'dhimmis', underordnet og tolerert, som de kristne i Syria. I Syria har de kristne bare

\section{På 6o-tallet kom de første koptisk- ortodokse kirkene utenfor regionen, $i$ Tyskland og England.}

rett til å gå i kirken." ${ }^{8}$ Rundt forrige århundreskifte gikk de kristne i Levanten etter hvert ut av den historiske rollen som "dhimmis", noe de muslimske massene sterkt misbilliget. Dette var på slutten av osmansk tid, riket ble svekket og gikk i oppløsning. De kristne maktene i Europa styrket sin stilling i hele regionen. De kristne i Midtøsten kom selv i en sterk posisjon; de hadde mektige venner i Vesten, de inntok en meget fordelaktig mellommannsrolle i økonomien og i mange av profesjonene. Som leger, advokater og apotekere hadde de en dominerende rolle, delvis basert på et tilnærmet kunnskapsmonopol. Denne gunstige posisjonen førte til sterkt redusert dødelighet og en økning av den kristne andel av befolkningen. Så annerledes alt er nå! Helt motsatt: Ingen mektige venner, ingen dominans i profesjonene, selv om deres andel fortsatt er uforholdsmessig høy, samt en utenrikshandel som i de fleste tilfeller er nasjonalisert og følgelig har fratatt de kristne mange av deres økonomiske privilegier. Kan man overhodet tenke seg at dagens situasjon nok en gang kan komme til å bli dramatisk endret til de kristnes fordel? Vanskelig å forestille 
seg. Hvis man så legger til den høyere politisk-religiøse temperaturen, vil da ikke de kristne, i noen land i alle fall, få en fremtid som moderne "dhimmis", men vil de godta det? Og vil de kristne trosretningene makte å slutte seg tettere sammen i vanskelige tider, eller vil de trekke seg inn i seg selv og dyrke sine særegenheter slik de gjorde i møtet med islam, i korsfarertiden og på slutten av mamelukherreveldet?

Avslutningvis ligger følgende vanskelige spørsmål i dagen: Hvilke kirkesamfunn vil ha den største "seigheten”, evnen til å bite seg fast, ikke bare som kirkeorganisasjon, men som kirkesamfunn? Hvilke av alle disse forskjellige trosretningene vil være $\mathrm{i}$ stand til overvinne dagens og morgendagens vanskeligheter, om noen? Spørsmålene får henge i luften. "Moderkirken" vil nok vare ved. I mange, mange år fremover vil det være en gresk-ortodoks patriark i Jerusalem, men vil patriarken, som nå, fortsette å ha en palestinsk menighet?

$$
\cdot f \cdot
$$

I “Midtøsten" refererer i denne artikkelen til Israel og de palestinske områdene, Libanon, Syria og Egypt.

2 Yrke og arbeidssted er tilsiktet uspesifikt beskrevet.

3 Dette er blant annet beskrevet i Egil Fossum: «Hos de kristne i Midtøsten», Oslo: Emilia, 2003.

4 Badr, Habib (red.): «Christianity. A History in the Middle East». Beirut: Middle East Council of Churches, 2005.

5 Horner, Norman A: «A Guide to Christian Churches in the Middle East». Elkart, IN: Mission Focus Publications, I989.

6 Pacini, Andrea (red.): «Christian Communities in the Arab Middle East». Oxford: Clarendon Press, I998.

7 Courbage, Youssef and Fargues, Philippe: «Christians and Jews in the Ottoman Empire». London: I.B. Tauris, I998.

8 Egil Fossum: «Hos de kristne i Midtøsten», s. Io०. 